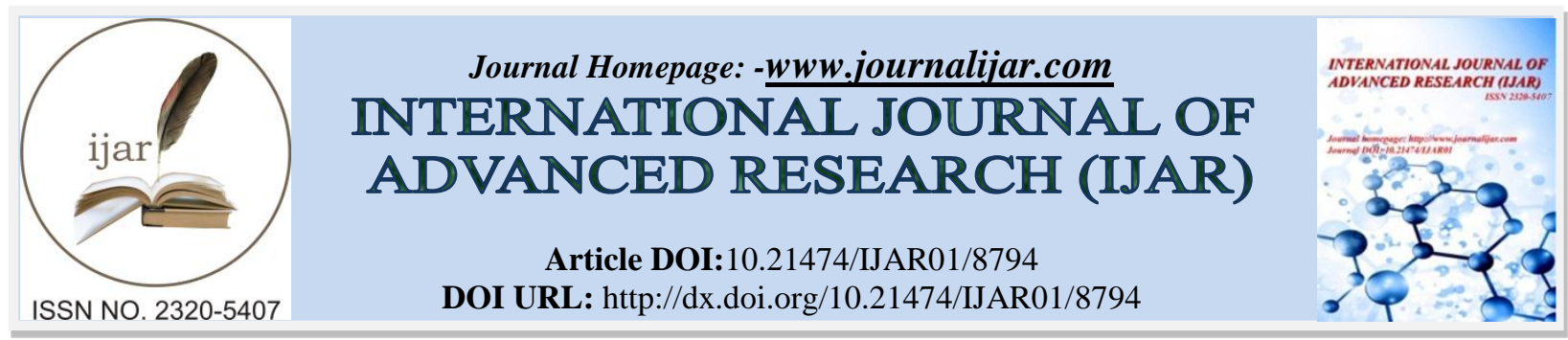

RESEARCH ARTICLE

\title{
CLINICAL AND BIOCHEMICAL EVALUATION OF THYMOQUINONE GEL IN THE TREATMENT OF CHRONIC PERIODONTITIS.
}

\author{
Ahmed Abdallah Khalil ${ }^{1}$ and Eman Alaaeldin ${ }^{2,3}$. \\ 1. Lecturer of Oral Medicine, Oral Diagnosis and Periodontology, Faculty of Dentistry, Minia University, Egypt. \\ 2. Department of Pharmaceutics, Faculty of Pharmacy, Minia University, Egypt. \\ 3. Department of Clinical pharmacy, Faculty of Pharmacy, Deraya University, Minia, Egypt.
}

\section{Manuscript Info}

\section{Manuscript History}

Final Accepted: 05 March 2019

Published: April 2019

Key words:-

Thymoquinone, IL-1 $\beta$, total anti-oxidant capacity, chronic periodontitis.
Received: 03 February 2019

\begin{abstract}
Aim of study: to investigate the effect of Thymoquinone gel on the clinical periodontal parameters as well as the level of IL-1 $\beta$ and total anti-oxidant capacity levels in gingival crevicular fluid of chronic periodontitis patients.

Patients and methods: This study was conducted on 68 subjects of both sexes with age ranged $25-58$ years old. 48 patients were clinically diagnosed with moderate to severe chronic periodontitis. The 68 subjects were grouped into three groups; Group I (24 patients): received non-surgical periodontal therapy and Thymoquinone gel $(0.1$ $\%$ w/w), Group II (24 patients): received only non-surgical periodontal therapy and Group III: 20 healthy subjects (control group). The clinical parameters including plaque index (PI), gingival index (GI), probing depth (PD) and clinical attachment level (CAL) as well as the level of IL-1 $\beta$ and total anti-oxidant capacity levels in gingival crevicular fluid were recorded at baseline (prior to treatment) and at weeks 4 and 12 after treatment.

Results: Groups I and II exhibited statistically significant differences in all clinical and biochemical parameters compared to baseline. Significant improvement in group I was detected at 4 weeks interval regarding biochemical parameters when compared to group II.

Conclusion: non-surgical periodontal therapy improves all clinical and biochemical parameters in both groups significantly. Adjunctive use of thymoqinon gel improve the biochemical parameters significantly after 4 weeks only.
\end{abstract}

Copy Right, IJAR, 2019,. All rights reserved.

\section{Introduction:-}

Periodontitis is a chronic inflammatory disease, characterized by gingival bleeding, periodontal pocket formation, connective tissue destruction and alveolar bone resorption leading to tooth loss (Pihlstrom BL et al., 2005).

Although oral bacteria, and their toxins, enzymes and metabolites, are considered to be the main causative factors for the initiation of inflammatory processes, the host inflammatory response is primarily responsible for the 
progression of the disease and for most of the connective tissues destruction (Di Paola et al. 2005, Bendyk A et al., 2009).

Bacterial pathogens stimulate host cells to release pro-inflammatory cytokines (e.g., interleukin-1 and tumor necrosis factor- $\alpha$ ) as part of the immune responses (Sculley DV, Langley-Evans SC 2003). These cytokines recruit polymorphonuclear leukocytes to the site of infection (Lamont RJ, Jenkinson LRJ, 1998). Inflammatory mediators are important to the pathogenesis of periodontal diseases and may be used as diagnostic markers. Interleukin (IL)-1 is present in two active forms, IL- $1 \alpha$ and IL-1 $\beta$. Both are potent Pro-inflammatory molecules and are the main components of osteoclast activating factor (M Mogi, 1999).Interleukin (IL)-1 is produced by macrophage, lymphocytes, monocyte, dendritic cells, lymphocytes, neutrophils, endothelial cells and fibroblasts (Stashenko P et al., 1991). Interleukin-1 $\beta$ (IL-1 $\beta$ ) is a potent Proinflammatory cytokine which plays a major role in inflammation and bone resorption, therefore, it becomes an important parameter in periodontal research (Bergmann A, Deinzer R., 2008).

Reactive oxygen species (ROS) have been implicated in the pathogenesis of many diseases, including rheumatoid arthritis (Mapp PI et al., 1995), chronic obstructive pulmonary disease (Macnee W, Rahman I, 1999), atherosclerosis (Halliwell B, 1993) and periodontal disease (Teng YT., 2003). Upon stimulation by bacterial antigens (e.g., lipopolysaccharide), polymorphonuclear leukocytes produce reactive oxygen species (ROS) via the oxidative burst and released into the extracellular environment. As the released ROS was not target-specific, damage to host tissue also occurs. (Sculley DV, Langley-Evans SC 2003).

When ROS attacks proteins and lipids, a series of nonenzymatic reactions occur to produce a large variety of intermediate and end products. Oxidative stress (OS) may be evaluated either by observing by-products of the interaction of ROS with lipids, proteins, and DNA or by examining alterations in total antioxidant capacity (TAOC) (Chevion $\mathrm{M}$ et al., 2000).

The total antioxidant capacity (TAOC) has been widely used to investigate OS in periodontal disease. It is an integrated parameter that reflects the cumulative activity of nonenzymatic antioxidants present in the plasma and body fluids (Baser U et al., 2015).

Many treatment modalities are available to achieve the goal of periodontal therapy. This includes nonsurgical periodontal therapy, such as scaling and root planing (SRP) alone or SRP plus systemic or local antimicrobial/antiinflammatory agents, and surgical periodontal therapy (Alam S et al., 2009).

Nigella sativa (NS), commonly known as black seed or black cumin, is an annual plant belonging to the Ranunculaceae family. Nigella sativa seeds contain diverse but well-characterized chemical components, many of which are capable of inducing beneficial pharmacological effects in humans (M. A. Randhawa and M. S. AlGhamdi, 2002).

Thymoquinone (TQ) is the major biologically active compound of N. sativa, is known as the bioactive constituent of the volatile black seed oil. TQ exhibits many pharmacological properties, which include antibacterial, antihistaminic, anti-inflammatory and hypoglycemic actions (Kara MI et al., 2012 \& Taka E. et al., 2015). TQ also displays an antioxidant response through its potent superoxide- scavenging ability (Nader MA et al., 2010).

The purpose of this research was to investigate the effect of TQ gel on the clinical periodontal parameters as well as the level of IL-1 $\beta$ and total anti-oxidant capacity levels in gingival crevicular fluid of chronic periodontitis patients.

\section{Subjects and Methods:- \\ Subject selection}

This study was conducted on 68 subjects of both sexes with age ranged 25-58 years old. Forty eight patients (19 males and 29 females) were clinically diagnosed with moderate to severe chronic periodontitis with at least 10 periodontal pockets with minimum depth $5 \mathrm{~mm}$, and twenty healthy subjects were chosen as volunteers for negative control group. The patients were selected from the out patients clinic of the Oral Medicine, Oral Diagnosis, and Periodontology Department. Faculty of Dentistry, Minia University.

All subjects were free of systemic disease and had not received any type of periodontal therapy, prescribed antibiotics or anti-inflammatory medication within the preceding 6 months. Pregnant, lactating females and smokers were excluded from the study. 


\section{Ethical regulations:}

The complete treatment plan was explained to all patients including detailed steps, risks, and expected results and their full signed consent was obtained prior to entry into the study. The study was complied with the rules set by the International Conference on Harmonization Good Clinical Practice Guidelines, and the Declaration of Helsinki and the research ethics committee of the Faculty of Dentistry, Mini University.

\section{Preparation of Thymoquinone gel:}

Thymoquinone gel was prepared in the department of pharmaceutics, faculty of pharmacy, Minia University. Chitosan gel of thymoquinone was prepared as follows: half of water required to form the gel was added to aqueous acetic acid ( $1 \% \mathrm{v} / \mathrm{v})$. The pre-weighed amount of chitosan was added gradually to the prepared acetic solution and was left to swell. The remaining amount of water was added to the swollen gel and mixed to form a final concentration of $1.8 \%$ (Mostafa, $\mathrm{M}$ et al., 2018). The formed gel was allowed to stand for 24 hour at room temperature before further treatment. Finally, about $5.5 \mathrm{ml}$ of freshly prepared aqueous thymoquinone suspension was dispersed into $10 \mathrm{gm}$ of chitosan gel to give a final TQ concentration of $0.1 \%(\mathrm{w} / \mathrm{w})$.

\section{Treatment Procedures:}

The 68 subjects were grouped into three groups:

\section{Group I (TQ group):}

1. 24 patients with moderate to severe chronic periodontitis received non-surgical periodontal therapy consisted of three sessions of scaling and root planning (SRP) for 2 weeks including full mouth supra and sub gingival scaling and root planning using hand instruments and ultrasonic scalers.

2. Periodontal pockets were filled with the TQ gel $0.1 \%(\mathrm{w} / \mathrm{w})$ immediately after completion of SRP with a blunt sterile needle until the gel could be observed at the gingival margin. The gel was applied again after 48 hours and the gel applied sites were covered with a periodontal pack for 7 days.

3. The patients were instructed to continue their oral hygiene procedures except the sites covered with dressing and after the removal of the dressing the operation site was washed with sterile saline.

\section{Group II:}

24 patients with moderate to severe chronic periodontitis received only non-surgical periodontal therapy as in group I.

\section{Group III (control group):}

Healthy subjects

\section{Assessment methods:}

\section{Clinical assessment:}

The clinical parameters including plaque index (PI), gingival index (GI), probing depth (PD) and clinical attachment level (CAL) were recorded at baseline (prior to treatment) and at weeks 4 and 12 after treatment in group I and II.

\section{Collection of Gingival crevicular fluid (GCF) Samples:}

1. The samples were collected from the GCF of group I and group II at baseline, 4 weeks and 12 weeks after treatment.

2. The GCF sample was collected in the mid-morning from the two groups of chronic periodontitis using Whatman3MM Chromatography (Wh.3MM) absorbent filter paper strips at baseline 4 and 12 weeks.

3. All participants were instructed not to eat anything or brush their teeth for at least $1 \mathrm{~h}$ before GCF collection to avoid interference with the GCF volume.

4. The supragingival plaque was removed from the sampling sites and isolated with cotton rolls. The sites were chosen from maxillary teeth to avoid contamination with saliva.

5. GCF samples were obtained only from the buccal sites to ensure accessibility and isolation and the areas were gently air dried.

6. The samples were pooled from 3 periodontal sites with attachment loss $4 \mathrm{~mm}$ or more (samples were taken from the same sites every interval).

7. The paper strip was placed into the gingival crevice up to $1 \mathrm{~mm}$ or until mild resistance was felt and left in the crevice for 30 seconds (Fig. 1).

8. Any strip contaminated by bleeding or exudate was discarded. 
9. The strips were individually placed in plastic Eppendorf and stored at -20C until be used for the laboratory analysis.

10. GCF from filter paper strips was diluted 1:2 - 1:20 into Reaction Buffer ultrafiltered through a 10,000 MWCO filter and used directly in the assay. The buffer used is deionized or distilled water. Samples were incubated and centrifuged at $4^{\circ} \mathrm{C}$.

11. Commercially available Enzyme linked immunosorbent assay (ELISA) kits were utilized, and assays were applied according to the manufacturers' instructions to examine the level of IL-1 $\beta$ and TAOC (Fig. 2).

12. The GCF sample was also collected from group III (control group) to determine the level of IL-1 $\beta$ and TAOC at baseline only.

\section{Results:-}

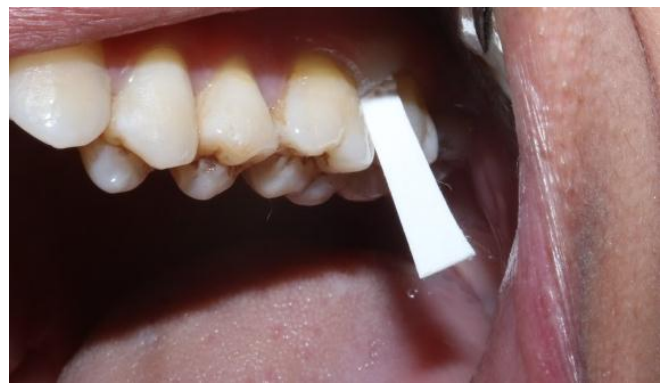

Fig 1:-The paper strip was placed into the gingival crevice

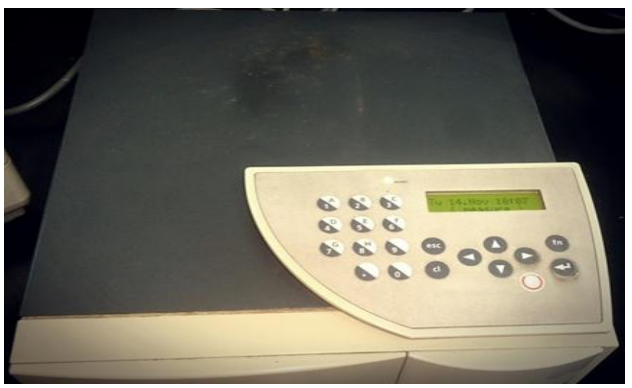

Fig 2:-ELISA reader

This study was conducted on 68 subjects of both sexes with age ranged 25-58 years old. Forty eight patients (19 males and 29 females) were clinically diagnosed with moderate to severe chronic periodontitis. The patients were selected from the out patients clinic of the Oral Medicine, Oral Diagnosis, and Periodontology Department. Faculty of Dentistry, Minia University. The 68 subjects were grouped into three groups; Group I (TQ group): received nonsurgical periodontal therapy and TQ gel, Group II: only non-surgical periodontal therapy and Group III: 20 healthy subjects.

The results of Clinical parameters:

The clinical parameters including plaque index (PI), gingival index (GI), probing depth (PD) and clinical attachment level (CAL) were recorded at baseline (prior to treatment) and at weeks 4 and 12 after treatment in group I and II.

Both groups showed significant improvement regarding all clinical parameters from baseline to 4 and 12 weeks after treatment.

The changes in the clinical parameters of the two studied patients groups are summarized in tables $(1,2)$.

Table 1:-The mean and standard deviation (SD) values of clinical parameters in group I at different intervals.

\begin{tabular}{|l|l|l|l|l|l|}
\hline Parameters & Baseline & After 4 weeks & after 12 weeks & $\begin{array}{l}\text { P-value } \\
\text { Base VS 4 } \\
\text { weeks }\end{array}$ & $\begin{array}{l}\text { P-value } \\
\text { Base VS 12 } \\
\text { weeks }\end{array}$ \\
\hline Gingival index (GI) & $1.82 \pm 0.47$ & $0.92 \pm 0.31$ & $0.45 \pm 0.37$ & $<0.0001$ & $<0.0001$ \\
\hline $\begin{array}{l}\text { Clinical attachment level } \\
(\mathrm{CAL})\end{array}$ & $4.22 \pm 0.62$ & $3.05 \pm 0.66$ & $1.75 \pm 0.63$ & $<0.0001$ & $<0.0001$ \\
\hline
\end{tabular}




\begin{tabular}{|l|l|l|l|l|l|}
\hline Pocket depth (PD) & $4.92 \pm 0.91$ & $3.25 \pm 0.98$ & $2.12 \pm 0.80$ & $<0.0001$ & $<0.0001$ \\
\hline
\end{tabular}

Table 2:-The mean, standard deviation (SD) values of clinical parameters in group II at different intervals.

\begin{tabular}{|l|l|l|l|l|l|}
\hline Parameters & Baseline & After 4 weeks & after 12 weeks & $\begin{array}{l}\text { P-value } \\
\text { Base VS 4 } \\
\text { weeks }\end{array}$ & $\begin{array}{l}\text { P-value } \\
\text { Base VS 12 } \\
\text { weeks }\end{array}$ \\
\hline Gingival index (GI) & $1.71 \pm 0.52$ & $0.89 \pm 0.57$ & $0.48 \pm 0.33$ & $<0.0001$ & $<0.0001$ \\
\hline Plaque index (PI) & $1.58 \pm 0.39$ & $0.78 \pm 0.41$ & $0.35 \pm 0.19$ & $<0.0001$ & $<0.0001$ \\
\hline $\begin{array}{l}\text { Clinical attachment level } \\
\text { (CAL) }\end{array}$ & $4.19 \pm 0.67$ & $3.28 \pm 0.88$ & $2.19 \pm 0.64$ & $<0.0001$ & $<0.0001$ \\
\hline Pocket depth (PD) & $4.83 \pm 0.74$ & $3.42 \pm 0.87$ & $2.37 \pm 0.76$ & $<0.0001$ & $<0.0001$ \\
\hline
\end{tabular}

\section{Biochemical evaluation:}

1. The samples were collected from the GCF of group I and group II at baseline, 4 weeks and 12 weeks after treatment. While, The GCF samples collected from group III were at baseline only.

2. Commercially available Enzyme linked immunosorbent assay (ELISA) kits were utilized, and assays were applied according to the manufacturers' instructions to examine the level of IL-1 $\beta$ and TAOC.

Results of IL-1 $\beta$ level in GCF:

Results of IL-1 $\beta$ in group I:

Descriptive changes in the mean values and stranded deviation of IL-1 $\beta$ at baseline and after periodontal therapy at different intervals in group I were shown in table (3). Comparison of the mean difference of IL-1 $\beta$ levels at different intervals were shown in table (4)

Table 3:-Descriptive statistics for the mean \pm stranded deviation values of IL-1 $\beta$ at different point of time in group I

\begin{tabular}{|l|l|l|l|}
\hline IL-1 $\boldsymbol{\beta}(\mathbf{p g} / \boldsymbol{\mu l})$ & $\mathrm{N}$ & Mean & Std. Deviation \\
\hline Baseline & 24 & 233.9938 & 25.11454 \\
\hline 4 weeks & 24 & 125.5479 & 19.21967 \\
\hline 12 weeks & 24 & 103.9525 & 10.84079 \\
\hline
\end{tabular}

Table 4:-Post Hoc multiple comparisons test (Bonferroni) for comparison of mean difference of IL-1 $\beta$ level at different intervals in group I

\begin{tabular}{|c|l|l|l|l|l|l|}
\hline (I) Time & (J) Time & $\begin{array}{l}\text { Mean } \\
\text { Difference (I- }\end{array}$ & Std. Error & Sig. & \multicolumn{2}{|c|}{$\begin{array}{l}\text { 95\% Confidence Interval for } \\
\text { Difference }\end{array}$} \\
\cline { 3 - 7 } & & & & & Lower Bound & Upper Bound \\
\hline \multirow{2}{*}{ Baseline } & 4 weeks & $108.446^{*}$ & 3.742 & $<0.0001$ & 98.785 & 118.107 \\
\cline { 2 - 7 } & 12 weeks & $130.041^{*}$ & 4.236 & $<0.0001$ & 119.104 & 140.978 \\
\hline 4 weeks & 12 weeks & $21.595^{*}$ & 2.114 & $<0.0001$ & 16.136 & 27.054 \\
\hline
\end{tabular}

A repeated measure ANOVA with a Greenhouse-Geisser correction was conducted to compare the effect of time on the IL-1 $\beta$ level after received non-surgical periodontal therapy and Thymoquinone gel. It was determined that mean IL-1 $\beta$ level differed statistically significantly between time points $(F=(1.39-32.07) 800.235, P<0.0001)$. Post hoc tests using the Bonferroni correction revealed that a reduction in IL-1 $\beta$ level from baseline to 4-weeks after treatment $(233.9938 \pm 25.11(\mathrm{pg} / \mu \mathrm{l})$ vs $125.5479 \pm 19.21(\mathrm{pg} / \mu \mathrm{l})$, respectively), which was statistically significant $(p$ $=<0.0001$ ). Additionally, after 12 weeks IL-1 $\beta$ level had been reduced to $103.9525 \pm 10.48 \mathrm{pg} / \mu \mathrm{l}$, which was statistically significantly different to baseline and 4-weeks after treatment.

\section{Results of IL-1ß in group II:}

Changes in the mean values and stranded deviation of IL-1 $\beta$ at baseline and after periodontal therapy at different intervals in group II were shown in table (5). Comparison of mean difference between level of IL-1 $\beta$ at different intervals in group II were shown in table (6) 
Table 5:-Descriptive statistics for the mean \pm stranded deviation values of IL-1 $\beta$ at different point of time in group II

\begin{tabular}{|l|l|l|l|}
\hline IL-1 $\boldsymbol{\beta}(\mathbf{p g} / \boldsymbol{\mu l})$ & N & Mean & Std. Deviation \\
\hline Baseline & 24 & 230.4958 & 24.73725 \\
\hline 4 weeks & 24 & 153.2650 & 27.30989 \\
\hline 12 weeks & 24 & 106.0400 & 9.50832 \\
\hline
\end{tabular}

Table 6:-Post Hoc multiple comparisons test (Bonferroni) for comparison of mean difference of IL-1 $\beta$ level at different point of time in group II

\begin{tabular}{|c|c|c|c|c|c|c|}
\hline \multirow[t]{2}{*}{ (I) Time } & \multirow[t]{2}{*}{ (J) Time } & \multirow[t]{2}{*}{$\begin{array}{l}\text { Mean } \\
\text { Difference (I-J) }\end{array}$} & \multirow[t]{2}{*}{ Std. Error } & \multirow[t]{2}{*}{ Sig. ${ }^{\mathrm{c}}$} & \multicolumn{2}{|c|}{$\begin{array}{lll}95 \% \quad \text { Confidence } & \text { Interval for } \\
\text { Difference } & \end{array}$} \\
\hline & & & & & Lower Bound & Upper Bound \\
\hline \multirow[t]{2}{*}{ Baseline } & 4 weeks & $77.231^{*}$ & 3.661 & .000 & 67.779 & 86.683 \\
\hline & 12 weeks & $124.456^{*}$ & 4.567 & .000 & 112.663 & 136.249 \\
\hline 4 weeks & 12 weeks & $47.225^{*}$ & 5.061 & .000 & 34.159 & 60.291 \\
\hline
\end{tabular}

A repeated measures ANOVA to compare the effect of time on the IL-1 $\beta$ level after received non-surgical periodontal only. It was determined that mean IL-1 $\beta$ level differed statistically significantly between time points, $P$ $<0.0001)$. Post hoc tests using the Bonferroni correction revealed that a reduction in IL-1 $\beta$ level from baseline to 4weeks after treatment $(230.49 \pm 24.73(\mathrm{pg} / \mu \mathrm{l})$ vs $153.26 \pm 27.31(\mathrm{pg} / \mu \mathrm{l})$, respectively), which was statistically significant $(\mathrm{p}=<0.0001)$. Additionally, after 12 weeks IL-1 $\beta$ level had been reduced to $106.4 \pm 9.50 \mathrm{pg} / \mu \mathrm{L}$, which was statistically significantly different to baseline and 4 -weeks after treatment.

\section{Comparison between level of IL-1 $\beta$ between group I and group II:}

Comparison between level of IL-1 $\beta$ between group I and group II at different intervals was shown in table (7). Comparison of IL-1 $\beta$ level between the three groups was shown in table $8 \& 9$.

Table 7:-Independent sample t- test to compare IL-1 $\beta$, between group I and group II at different intervals.

\begin{tabular}{|l|l|l|l|}
\hline \multirow{2}{*}{ Time Point } & \multicolumn{2}{|l|}{ Proups } & \multirow{2}{*}{-value } \\
\cline { 2 - 3 } & $\begin{array}{l}\text { Group I } \\
\text { Mean } \pm \text { SD }\end{array}$ & $\begin{array}{l}\text { Group II } \\
\text { Mean } \pm \text { SD }\end{array}$ & \\
\hline IL-1 $\beta(\mathbf{p g} / \boldsymbol{\mu l})$ Baseline & $233.99 \pm 25.11$ & $230.49 \pm 24.73$ & 0.6 \\
\hline IL-1 $\beta(\mathbf{p g} / \boldsymbol{\mu l})$ After 4 weeks & $125.54 \pm 19.21$ & $153.26 \pm 27.31$ & $<0.0001$ \\
\hline IL-1 $\beta(\mathbf{p g} / \boldsymbol{\mu l})$ After 12 weeks & $103.95 \pm 10.84$ & $106.04 \pm 9.51$ & 0.4 \\
\hline
\end{tabular}

Table 8:-Anova test to compare IL-1 $\beta$ at baseline, between group I, group II and group III

\begin{tabular}{|c|c|c|c|c|c|c|}
\hline & \multicolumn{3}{|l|}{ Groups } & \multirow{2}{*}{$\begin{array}{l}\text { GI } \\
\text { vs GII }\end{array}$} & \multirow{2}{*}{$\begin{array}{l}\text { GI } \\
\text { vs } \\
\text { GIII }\end{array}$} & \multirow{2}{*}{$\begin{array}{l}\text { GII } \\
\text { vs } \\
\text { GIII }\end{array}$} \\
\hline & $\begin{array}{l}\text { GroupI } \\
\text { Mean } \pm \text { SD }\end{array}$ & $\begin{array}{l}\text { GroupII } \\
\text { Mean } \pm \text { SD }\end{array}$ & $\begin{array}{l}\text { GroupIII } \\
\text { Mean } \pm \text { SD }\end{array}$ & & & \\
\hline $\begin{array}{l}\text { IL-1 } \quad \beta \quad(p g / \mu l) \\
\text { Baseline }\end{array}$ & $233.99 \pm 25.11$ & $230.49 \pm 24.73$ & $101.42 \pm 12.59$ & 1.00 & 0.0001 & 0.0001 \\
\hline
\end{tabular}

Table 9:-Independent sample t- test to compare IL-1 $\beta$, between group I and group II after 12 weeks and group III at baseline

\begin{tabular}{|l|l|l|l|l|l|}
\hline & Groups & GI & GII \\
\cline { 2 - 6 } & $\begin{array}{l}\text { Group I after 12 } \\
\text { weeks } \\
\text { Mean } \pm \text { SD }\end{array}$ & $\begin{array}{l}\text { Group II after 12 } \\
\text { weeks } \\
\text { Mean } \pm \text { SD }\end{array}$ & $\begin{array}{l}\text { Group III at baseline } \\
\text { Mean } \pm \text { SD }\end{array}$ & $\begin{array}{l}\text { Vs } \\
\text { GIII }\end{array}$ & $\begin{array}{l}\text { Gs } \\
\text { GII }\end{array}$ \\
\hline IL-1 $\boldsymbol{\beta}(\mathbf{p g} / \boldsymbol{\mu l})$ & $103.95 \pm 10.84$ & $106.04 \pm 9.51$ & $101.42 \pm 12.59$ & 0.4 & 0.1 \\
\hline
\end{tabular}




\section{Results of TAOC level in GCF: \\ Results of TAOC in group I:}

Descriptive changes in the mean values and stranded deviation of TAOC at baseline and after periodontal therapy at different intervals in group I were shown in table (10). Comparison of the mean difference of TAOC levels at different intervals were shown in table (11)

Table 10:-Descriptive statistics for the mean \pm stranded deviation values of TAOC at different point of time in group I

\begin{tabular}{|l|l|l|l|}
\hline TAOC $(\boldsymbol{\mu m} / \mathbf{l})$ & $\mathrm{N}$ & Mean & Std. Deviation \\
\hline Baseline & 24 & 647.3767 & 22.06623 \\
\hline 4 weeks & 24 & 739.5458 & 15.88813 \\
\hline 12 weeks & 24 & 773.7388 & 14.68271 \\
\hline
\end{tabular}

Table 11:-Post Hoc multiple comparisons test (Bonferroni) for comparison of mean difference of TAOC level at different point of time in group I

\begin{tabular}{|c|c|c|c|c|c|c|}
\hline \multirow[t]{2}{*}{ (I) factor 1} & \multirow[t]{2}{*}{$(\mathrm{J})$ factor 1} & \multirow[t]{2}{*}{$\begin{array}{l}\text { Mean } \\
\text { Difference (I-J) }\end{array}$} & \multirow[t]{2}{*}{ Std. Error } & \multirow[t]{2}{*}{ Sig. ${ }^{c}$} & \multicolumn{2}{|c|}{$\begin{array}{l}\text { 95\% Confidence } \\
\text { Difference }\end{array}$} \\
\hline & & & & & Lower Bound & Upper Bound \\
\hline \multirow[t]{2}{*}{ Baseline } & 4 weeks & $-92.169-{ }^{*}$ & 5.952 & $<0.0001$ & $-107.538-$ & $-76.800-$ \\
\hline & 12 weeks & $-126.362^{*}$ & 4.515 & $<0.0001$ & $-138.021-$ & $-114.703-$ \\
\hline 4 weeks & 12 weeks & $-34.193-^{*}$ & 4.584 & $<0.0001$ & $-46.029-$ & $-22.357-$ \\
\hline
\end{tabular}

A repeated measures ANOVA was conducted to compare the effect of time on the TAOC level after received nonsurgical periodontal therapy and Thymoquinone gel. It was determined that mean TAOC level differed significantly between time points $(F=(1.39-32.07) 800.235, P<0.0001)$. Post hoc tests using the Bonferroni correction revealed that an increase in TAOC level from baseline to 4-weeks after treatment $(647.3767 \pm 22.06(\mu \mathrm{m} / \mathrm{l})$ vs $739.5458 \pm$ $15.88(\mu \mathrm{m} / \mathrm{l})$, respectively), which was statistically significant $(p=<0.0001)$. Additionally, after 12 weeks TAOC level had been increased to $773.7388 \pm 14.68 \mu \mathrm{m} / \mathrm{l}$, which was significantly different to baseline and 4-weeks after treatment.

\section{Results of TAOC in group II:}

Descriptive changes in the mean values and stranded deviation of TAOC at baseline and after periodontal therapy at different intervals in group I were shown in table (12). Comparison of the mean difference of TAOC levels at different intervals were shown in table (13)

Table 12:-Descriptive statistics for the mean \pm stranded deviation values of TAOC at different point of time in group II

\begin{tabular}{|l|l|l|l|}
\hline TAOC $(\boldsymbol{\mu m} / \mathbf{l})$ & $\mathrm{N}$ & Mean & Std. Deviation \\
\hline Baseline & 24 & 644.2200 & 17.02155 \\
\hline 4 weeks & 24 & 723.9104 & 12.62703 \\
\hline 12 weeks & 24 & 762.9683 & 12.84764 \\
\hline
\end{tabular}

Table 13:-Post Hoc multiple comparisons test (Bonferroni) for comparison of mean difference of TAOC level at different point of time in group II

\begin{tabular}{|c|c|c|c|c|c|c|}
\hline \multirow[t]{2}{*}{ (I) factor 1} & \multirow[t]{2}{*}{$(\mathrm{J})$ factor 1} & \multirow[t]{2}{*}{$\begin{array}{l}\text { Mean } \\
\text { Difference (I-J) }\end{array}$} & \multirow[t]{2}{*}{ Std. Error } & \multirow[t]{2}{*}{ Sig. ${ }^{c}$} & \multicolumn{2}{|c|}{$\begin{array}{l}\text { 95\% Confidence Interval for } \\
\text { Difference }^{c}\end{array}$} \\
\hline & & & & & Lower Bound & Upper Bound \\
\hline \multirow[t]{2}{*}{ Baseline } & 4 weeks & $-79.690-^{*}$ & 4.188 & $<0.0001$ & -90.504- & $-68.877-$ \\
\hline & 12 weeks & $-118.748-^{*}$ & 4.980 & $<0.0001$ & $-131.608-$ & $-105.889-$ \\
\hline 4 weeks & 12 weeks & $-39.058-^{*}$ & 3.363 & $<0.0001$ & $-47.741-$ & $-30.374-$ \\
\hline
\end{tabular}

A repeated measures ANOVA was conducted to compare the effect of time on the TAOC level after received nonsurgical periodontal therapy only. It was determined that mean TAOC level differed statistically significantly 
between time points $(F=(1.39-32.07) 800.235, P<0.0001)$. Post hoc tests using the Bonferroni correction revealed that an increase in TAOC level from baseline to 4 -weeks after treatment $(644.2200 \pm 17.02(\mu \mathrm{m} / \mathrm{l})$ vs $723.9104 \pm$ $12.62(\mu \mathrm{m} / \mathrm{l})$, respectively), which was statistically significant $(p=<0.0001)$. Additionally, after 12 weeks TAOC level had been increased to $762.9683 \pm 12.84 \mu \mathrm{m} / \mathrm{l}$, which was statistically significantly different to baseline and 4 weeks after treatment.

Comparison between level of TAOC between group I and group II:

Comparison between level of TAOC between group I and group II at different intervals was shown in table (14). Comparison of TAOC at baseline between the three groups was shown in table $15 \& 16$

Table 14:-Independent sample t- test to compare TAOC, between group I and group II at different point of time

\begin{tabular}{|l|l|l|l|}
\hline Time Point & Groups & \multirow{2}{*}{ P-value } \\
\cline { 2 - 3 } & $\begin{array}{l}\text { Group I } \\
\text { Mean } \pm \text { SD }\end{array}$ & $\begin{array}{l}\text { Group II } \\
\text { Mean } \pm \text { SD }\end{array}$ & \\
\hline TAOC $(\boldsymbol{\mu m} / \mathbf{l})$ Baseline & $647.37 \pm 22.06$ & $644.22 \pm 17.02$ & 0.5 \\
\hline TAOC $(\boldsymbol{\mu m} / \mathbf{l})$ After 4 weeks & $739.54 \pm 15.88$ & $723.91 \pm 12.62$ & $<0.0001$ \\
\hline TAOC $(\boldsymbol{\mu m} / \mathbf{l})$ After 12 weeks & $773.73 \pm 14.68$ & $762.96 \pm 12.84$ & 0.01 \\
\hline
\end{tabular}

Table 15:-Anova test to compare TAOC, between group I, group II and group III at baseline

\begin{tabular}{|l|l|l|l|l|l|l|}
\hline \multirow{2}{*}{ Time Point } & \multicolumn{2}{|l|}{ Groups } & GI & GI \\
\cline { 2 - 6 } & $\begin{array}{l}\text { Group I } \\
\text { Mean } \pm \text { SD }\end{array}$ & $\begin{array}{l}\text { Group II } \\
\text { Mean } \pm \text { SD }\end{array}$ & $\begin{array}{l}\text { Group III } \\
\text { Mean } \pm \text { SD }\end{array}$ & $\begin{array}{l}\text { GII } \\
\text { GII }\end{array}$ & $\begin{array}{l}\text { GIII } \\
\text { GIII }\end{array}$ \\
\hline $\begin{array}{l}\text { TAOC } \\
(\mu \mathrm{m} / \mathbf{l}) \text { Baseline }\end{array}$ & $647.37 \pm 22.06$ & $644.22 \pm 17.02$ & $843.33 \pm 22.52$ & 1.00 & 0.0001 & 0.0001 \\
\hline
\end{tabular}

Table 16:-Independent sample t- test to compare TAOC, between group I and group II after 12 weeks and group III at baseline

\begin{tabular}{|l|l|l|l|l|l|}
\hline & Groups & GI \\
\cline { 2 - 5 } & $\begin{array}{l}\text { Group I after 12 } \\
\text { weeks } \\
\text { Mean } \pm \text { SD }\end{array}$ & $\begin{array}{l}\text { Group II after 12 } \\
\text { weeks } \\
\text { Mean } \pm \text { SD }\end{array}$ & $\begin{array}{l}\text { Group III at } \\
\text { baseline } \\
\text { Mean } \pm \text { SD }\end{array}$ & $\begin{array}{l}\text { GII } \\
\text { GIII } \\
\text { GIII }\end{array}$ \\
\hline TAOC $(\boldsymbol{\mu m} / \mathbf{l})$ & $773.73 \pm 14.68$ & $762.96 \pm 12.84$ & $843.33 \pm 22.52$ & 0.0001 & 0.0001 \\
\hline
\end{tabular}

\section{Discussion:-}

Periodontitis is an inflammatory disease leads to local elevation in levels of pro-inflammatory cytokine which plays a vital role in the process of inflammation associated with the destruction of the periodontium (Teng YT. 2006, Reher VG. et al., 2007). IL-1 $\beta$ is a cell immune response mediator released as an outcome of bacterial components as lipopolysaccharides. This cytokine increases the neutrophils recruitment and the expression of adhesion molecules and it can result in destruction of periodontal tissue (Lö YJ. et al., 1999). Measurement of IL-1 $\beta$, in gingival crevicular fluid (GCF) or tissues adjacent to periodontitis-affected sites in patients, has been suggested as a sensitive and remarkable method in monitoring severity of periodontal disease (Hou LT. et al, 1995). Hence, IL-1 $\beta$ would seem an attractive candidate molecule for monitoring periodontal disease initiation, progression, and therapeutic outcome. (McGuire \& Nunn,1999)

It is a well-known fact that free radicals and reactive oxygen species (ROS) are essential for many normal biologic processes. At low concentration, these free radicals stimulate the growth of fibroblasts and epithelial cells in culture, but at higher concentrations it may result in tissue injury (Battino M. et al., 1995). However, Oxidative stress (OS) promotes the pathophysiological progression of periodontal disease by triggering local and systemic inflammatory responses (Baltacıoğlu E. et al., 2014, \& Torumtay G. et al., 2016).

The measurement of total antioxidant capacity (TAOC) was developed as a cost-effective tool to assess the activity of the whole antioxidant system (Chapple et al., 1997). Assays of TAOC have the advantage of analyzing the combined effectiveness of contributing antioxidant species, which may be greater than the sum of the effects of the individual antioxidant (Maxwell SR et al., 2006) 
The fact that the bacteria in the subgingival area are organised in a biofilm, which seriously limits the effectiveness of antimicrobials (Brown \& Gilbert 1993), so, the use of local drug therapy adjuntively to scaling and root planing is better than as a monotherapy (Tonetti 1997).

Thymoquinone is considered to be the main active ingredient in nigella sativa oil (M. A. Randhawa and M. S. AlGhamdi, 2002). Pharmacological investigations of NS seed extracts reveal a broad spectrum of activities including antioxidant (A. A. Mariod, et al., 2009) anti-inflammatory (A. Ragheb et al., 2009) and antimicrobial (T. Allahghadri et al., 2010)activities.

Thymoquinone, the main active constituent of Nigella sativa, exhibits anti-oxidant effect (A. A. Mariod, et al., 2009) and bactericidal effects against both Gram-positive and Gram-negative bacteria, and even shows synergistic effects when combined with other antibiotics (T. Allahghadri et al., 2010).

To evaluate the effect of TQ gel on the clinical periodontal parameters as well as the level of IL-1 $\beta$ and total antioxidant capacity levels in gingival crevicular fluid, two groups of patients with chronic periodontitis were either submitted to combined pharmacological and clinical treatment (Group I) or single clinical treatment (group II).

Periodontal probing depth, clinical attachment level, gingival index and plaque index as well as the level of IL-1 $\beta$ and total anti-oxidant capacity were recorded in the two groups at baseline (prior to treatment), 4 and 8 weeks.

Regarding the clinical parameters, a statistically-significant improvement, compared to base line, was found in both groups after 4 and 12 weeks of treatment. Although group I showed more clinical improvement compared to group II, it was not statistically significant.

The clinical improvement in both groups may be attributed to the non-surgical periodontal therapy, employed in the study; since scaling and root planning treatment approach in periodontal therapy is an efficient method to reduce the amount of calculus and biofilm bacteria attached to the sub-gingival root surface. It also induces beneficial changes to the periodontal tissues, as reduction of the gingival inflammation, reduction of probing pocket depth, and gain in clinical attachment level (Adriaens and Adriaens, 2004).

Regarding the biochemical improvement, the elevated base line of IL- $1 \beta$ in patients with periodontitis (groups I, II) compared to that of healthy volunteers (group III) was in consistence with the results of many studies (Orozco A et al., 2006, Chaudhari AU et al., 2011\& Lukasz Gilowski, 2014). IL-1 $\beta$ Concentration in GCF was significantly decreased in both groups after 4 and 12 weeks of treatment compared to the base line concentration of each individual group.

Concerning TAOC level, the results of the present study have shown that there was significant increase in the TAOC level after 4 and 12 weeks of treatment compared to baseline in each individual treatment group. When comparing the level of TAOC of group I and group II at baseline with group III, significant differences were found.

The data from the present study are in agreement with the results of Pavlica (Pavlica et al., 2004) who found positive relations between plasma TAOC and periodontitis in dogs. Also, our results are consistent with (Brock et al., 2004) who found that the mean total antioxidant concentrations of serum and plasma from patients with periodontal disease were lower than healthy control samples, and the results of Chapple (Chapple et al.,2002) who reported that GCF glutathione values and TAOC in plasma and GCF are reduced in chronic periodontitis.

Regarding Biochemical results, there was significant improvement in group I compared to group II after 4 weeks of treatment. That may be attributed to the anti-oxidant effect of TQ (A. A. Mariod, et al., 2009 \&A. Ragheb et al., 2009). Unfortunately, there was no significant improvement in biochemical results in group I compared to group II after 4 weeks of treatment. That may be attributed to physical instability and photosensitivity (Salmani J.M. et al., 2014) rapid elimination, binding to plasma proteins of TQ (more than 99\%) (Alkharfy, K.M. et al., 2015). All these factors limit the clinical and biochemical improvement in group I after 4 weeks of treatment and explain the insignificant improvement after 12 weeks.

\section{Conclusions:-}

According to our results, non-surgical periodontal therapy improves all clinical and biochemical parameters in both groups significantly. Adjunctive use of thymoqinone gel showed significant improvement in the biochemical parameters after 4 weeks of treatment compared to single non-surgical periodontal therapy. Adjunctive therapy of 
TQ has failed to maintain that significant improvement after 12 weeks of treatment due to the instability and pharmacokinetics of the drug. Further studies should be established to enhance the physicochemical properties and pharmacokinetics of the drug.

\section{References:-}

1. ADRIAENS, P. A. \& ADRIAENS, L. M. (2004). Effects of nonsurgical periodontal therapy on hard and soft tissues. Periodontology 2000, 36, 121-145.

2. Alam S, Ueki K, Nakagawa K, et al. (2009) Statin-induced bone morphogenetic protein (BMP) 2 expression during bone regeneration: An immunohistochemical study. Oral Surg Oral Med Oral Pathol Oral Radiol Endod;107:22-29.

3. Alkharfy, K.M.; Ahmad, A.; Khan, R.M.; Al-Shagha, W.M. (2015) Pharmacokinetic plasma behaviors of intravenous and oral bioavailability of thymoquinone in a rabbit model. Eur. J. Drug Metab. Pharmacokinet., 40, 319-323.

4. Baltacıoğlu E, Yuva P, Aydın G, Alver A, Kahraman C, Karabulut E et al. (2014) Lipid peroxidation levels and total oxidant/antioxidant status in serum and saliva from patients with chronic and aggressive periodontitis. Oxidative stress index: a new biomarker for periodontal disease? J Periodontol ;85(10):1432-41.

5. Baser U, Gamsiz-Isik H, Cifcibasi E, Ademoglu E, Yalcin F (2015) Plasma and salivary total antioxidant capacity in healthy controls compared with aggressive and chronic periodontitis patients. Saudi Med J 36(7):856-861.

6. Battino M, Gorini A, Villa RF, Genova ML, Bovina C, Sassi S et al.(1995) Coenzyme Q content in synaptic and non synaptic mitochondria from different brain regions in ageing rats. Mech Ageing Dev:78:173-87.

7. Bendyk A, Marino V, Zilm PS, Howe P, Bartold PM. (2009) Effect of dietary omega-3 polyunsaturated fatty acids on experimental periodontitis in the mouse. J Periodontal Res;44:211-216.

8. Bergmann A, Deinzer R.(2008) Daytime variations of interleukin-1beta in gingival crevicular fluid. Eur J Oral Sci.; 116(1):18-22.

9. Brock GR, Butterworth CJ, Matthews JB, Chapple IL.(2004) Local and systemic total antioxidant capacity in periodontitis and health. J Clin Periodontol; 31:515- 521.

10. Brown, M. \& Gilbert, P. (1993) Sensitivity of biofilms to antimicrobial agents. Journal of Applied Bacteriology 74 (suppl.), 87S- 97S.

11. Chapple IL, Brock GR, Eftimiadi C, Matthews JB.(2002) Glutathione in gingival crevicular fluid and its relation to local antioxidant capacity in periodontal health and disease. Mol Pathol; 55:367-373.

12. Chapple, I. L., Mason, G. I., Garner, I., Matthews, J. B., Thorpe, G. H., Maxwell, S. R., et al. (1997). Enhanced chemiluminescent assay for measuring the total antioxidant capacity of serum, saliva and crevicular fluid. Ann. Clin. Biochem. 34 (Pt 4), 412-421.

13. Chaudhari AU, Byakod GN, waghmare PF, Krarhadkar VM (2011) correlation level of IL-1 $\beta$ in gingival crevicular fluid to the clinical. parameters of chronic periodentitis. Journal of contemporaryDental practice; 12(1):52-59.

14. Chevion M, Berenshtein E, Stadtman ER. (2000) Human studies related to protein oxidation: protein carbonyl content as a marker of damage. Free Radic Res.;33 Suppl:S99-108.

15. Di Paola R, Mazzon E, ZitoDet al. (2005)Effects of Tempol, a membrane-permeable radical scavenger, in a rodent model periodontitis. J Clin Periodontol ;32:1062-1068.

16. Halliwell B. (1993) The role of oxygen radicals in human disease, with particular reference to the vascular system. Haemostasis; 1 (suppl.):118-126.

17. Hou LT, Liu CM, Rossomando EF.(1995) Crevicular interleukin-1beta in moderate and severe periodontitis patients and the effect of phase I periodontal treatment. J Clin Periodontol;22:162.

18. Kara MI, Erciyas K, Altan AB, et al. (2012) Thymoquinone accelerates new bone formation in the rapid maxillary expansion procedure. Arch Oral Biol.;57:357-363.

19. Lamont RJ, Jenkinson LRJ. (1998) Life below the gum line: pathogenic mechanisms of Porphyromonas gingivalis. Microbiol Mol Biol Rev; 62:1244-63.

20. Lö YJ, Liu CM, WongMY, Hou LT, et al. (1999). Interleukin 1beta-secreting cells in inflamed gingival tissue of adult periodontitis patients. Cytokine; 11: 626-633

21. Lukasz Gilowski.(2014) Amount of interleukin-1 $\beta$ and interleukin-1 receptor antagonist in periodontitis and healthy patients. Archives of Oral Biology; 59(7):729-734.

22. M Mogi, J Otogoto,N Ota, H Inagaki, M Minami,K Kojima.(1999) Interleukin $1 \beta$, interleukin 6, $\beta 2-$ microglobulin, and transforming growth factor- $\alpha$ in gingival crevicular fluid from human periodontal diseaseArchives of Oral Biology.; Volume 44, Issue 6, Pages 535- 539. 
23. M. A. Randhawa and M. S. Al-Ghamdi, (2002) "A review of the pharmacotherapeutic effects of Nigella sativa," Pakistan Journal of Medical Research, vol. 41, pp. 77-83.

24. M. A. Randhawa and M. S. Al-Ghamdi,(2002) "A review of the pharmacotherapeutic effects of Nigella sativa," Pakistan Journal of Medical Research, vol. 41, pp. 77-83.

25. Macnee W, Rahman I. (1999) Oxidants and antioxidants as therapeutic targets in chronic obstructive pulmonary disease. Am J Resp Crit Care Med;160:S58- S65.13.

26. Mapp PI, Grootveld MC, Blake DR. (1995) Hypoxia, oxidative stress and rheumatoid arthritis. Br Med Bull; 51:419-436.

27. Mariod, R. M. Ibrahim, M. Ismail, and N. Ismail, (2009) "Antioxidant activity and phenolic content of phenolic rich fractions obtained from black cumin (Nigella sativa) seedcake," Food Chemistry, vol. 116, no. 1, pp. 306312.

28. Maxwell SR, Dietrich T, Chapple I(2006)L. Prediction of serum total antioxidant activity from the concentration of individual serum antioxidants. Clin Chim Acta ;372:188-194.

29. McGuire, M. K. \& Nunn, M. E. (1999) Prognosis versus actual outcome. IV. The effectiveness of clinical parameters and IL-1 genotype in accurately predicting prognoses and tooth survival. J Periodontol 70, 49-56.

30. Mostafa, M., E. Alaaeldin, et al. (2018). "Optimization and Characterization of Thymoquinone-Loaded Liposomes with Enhanced Topical Anti-inflammatory Activity." AAPS PharmSciTech 19(8): 3490-3500.

31. Nader MA, El-Agamy DS, Suddek GM.(2010) Protective effects of propolis and thymoquinone on development of atherosclerosis in cholesterol-fed rabbits. Arch Pharm Res.;33:637-643.

32. Orozco A, Gemmell E, Bickel M, Seymour GJ.(2006) Interleukin-1 b, interleukin-12 and inter- leukin-18 levels in gingival fluid and serum of patients with gingivitis and periodontitis .Oral Microbiol Immunol.;21: 256 - 260.

33. Pavlica Z, Petelin M, Nemec A, Erzen D, Skaleric .(2004) Measurement of total antioxidant capacity in gingival crevicular fluid and serum in dogs with periodontal disease. Am J Vet Res;65:1584-1588.

34. Pihlstrom BL, Michalowicz BS, Johnson NW. (2005) Periodontal disease. Lancet;366:1809—20.

35. Ragheb, A. Attia,W. S. Eldin, F. Elbarbry, S. Gazarin, and A. Shoker, (2009) "The protective effect of thymoquinone, an anti-oxidant and anti-inflammatory agent, against renal injury: a review," Saudi Journal of Kidney Diseases and Transplantation, vol. 20, no. 5, pp. 741-752.

36. Reher VG, Zenobio EG, Costa FO, Reher P, et al. (2007) Nitric oxide levels in saliva increase with severity of chronic periodontitis. J. Oral Sci.;49: 271-276.

37. Salmani, J.M.; Asghar, S.; Lv, H.X.; Zhou, J.P. (2014) Aqueous solubility and degradation kinetics of the phytochemical anticancer thymoquinone; probing the effects of solvents, $\mathrm{pH}$ and light. Molecules, 19, 59255939.

38. Sculley DV, Langley-Evans SC (2003) Periodontal disease is associated with lower antioxidant capacity in whole saliva and evidence of increased protein oxidation. Clin Sci (Lond) 105(2):167-172. doi:10.1042/CS20030031

39. Stashenko P, Fujiyoshi P, Obernesser MS, Prostak L, Haffajee AD, Socransky SS. (1991) Levels of interleukin 1 beta in tissue from sites of active periodontal disease. J Clin Periodontol.;18:548-54.

40. T. Allahghadri, I. Rasooli, P. Owlia et al.,(2010) "Antimicrobial property, antioxidant capacity, and cytotoxicity of essential oil from cumin produced in Iran," Journal of Food Science, vol. 75, no. 2 pp. H54-H61.

41. Taka E, Mazzio EA, Goodman CB, et al.(2015) Anti-inflammatory effects of thymoquinone in activated BV-2 microglial cells. J Neuroimmunol;286:5-12.

42. Teng YT. (2003) The role of acquired immunity and periodontal disease progression. Crit Rev Oral Biol Med;14:237-252.

43. Teng YT. (2006) Protective and destructive immunity in the periodontium: Part 1 - innate and humoral immunity and the periodontium. J.Dent. Res.; 85: 198-208.

44. Tonetti, M. S. (1997) The use of topical antibiotics in periodontal pockets. In: Proceedings of the 2nd European Workshop on periodontology, eds. Lang, N. P., Karring, T. \& Lindhe, J. Quintessence Publ.: Berlin. pp 78-109.

45. Torumtay G, Kırzıoğlu FY, Öztürk Tonguç M, Kale B, Calapoğlu M, Orhan H. (2016) Effects of periodontal treatment on inflammation and oxidative stress markers in patients with metabolic syndrome. J Periodontal Res. 51(4):489-98. 